\title{
Optimization and Adsorption-Based Recovery of Cobalt Using Activated Disordered Mesoporous Carbons
}

\author{
I. Bernabé, J.M. Gómez (D, E. Díez, P. Sáez, and A. Rodríguez \\ Catalysis and Separation Processes Group, Chemical Engineering and Materials Department, Complutense University of Madrid, \\ 28040 Madrid, Spain
}

Correspondence should be addressed to J.M. Gómez; segojmgm@ucm.es

Received 13 December 2018; Revised 18 March 2019; Accepted 15 April 2019; Published 7 May 2019

Academic Editor: Jun Liu

Copyright (c) 2019 I. Bernabé et al. This is an open access article distributed under the Creative Commons Attribution License, which permits unrestricted use, distribution, and reproduction in any medium, provided the original work is properly cited.

Kinetic and operating condition studies were studied in the batch mode. MCSG60A has a large and fast adsorption capacity, retaining $90 \%$ of the $\mathrm{Co}^{2+}$ in the solution and reaching equilibria in only 15 minutes. Among all the variables studied, the adsorbent dosage and the agitation speed favor the $\mathrm{Co}^{2+}$ adsorption until an agitation speed of $1100 \mathrm{rpm}$ and $15.0 \mathrm{mg} / \mathrm{L}$ of adsorbent dosage; higher values do not increase the adsorption capacity. On the other hand, the presence of $\mathrm{Na}^{+}$ions in the solution and high particle size hinder the adsorption process. The thermodynamic study indicated that this process is exothermic and spontaneous, mainly caused by electrostatic interactions between adsorbent and adsorbate. The adsorption is highly $\mathrm{pH}$ dependent: while it is optimum at basic $\mathrm{pH}$, it decreases by a $70 \%$ at $\mathrm{pH} 2$. The adsorption process is favored in controlled $\mathrm{pH}$, in spite of the ionic strength that involves the buffer presence in the solution. As to the cobalt recovery, to preconcentrate this metal, it is tested with different acid solutions, proving that lower $\mathrm{pH}$ promotes this phenomena, even reaching a recovery around $98 \%$, with $\mathrm{HNO}_{3}$ solution with $0.5 \mathrm{pH}$. Moreover, if the volume of regenerative solution is decreased to the eight part, the cobalt concentration increases five times, reaching enough concentration to facilitate its recovery in metallic state by other techniques.

\section{Introduction}

Several studies have reported that the increasing industrial activity (mainly mining operations, manufacturing of electronic devices, electroplating, and petrochemistry) has boosted heavy metal concentration in water, what is considered a menace for both environment and society [1], due to their nondegradability and toxicity. Among all these heavy metals, some of them such as gallium, indium, and cobalt are considered strategic metals, due to the increase in their consumption and scarce. As a matter of fact, cobalt is one of the most interesting to be removed and recovered since not only it causes neurotoxicological disorders and cancer [2] but also, due to the increase in its consumption, is mainly used for the manufacture of electronic devices [3].

Cobalt is used in a wide range of applications; however, it is mainly used for manufacturing rechargeable battery electrodes and super alloys, resistant to corrosion and wear, which are used for gas turbine engines. Further applications are catalysts for chemical industries, magnets, steel-belted radial tires, and airbags. Every year, its consumption is increasing and its production is decreasing. Consequently, this increases its economic importance. For instance, in 2015 , the cobalt consumption increased $8 \%$ more than the year before. However, it is important to bear in mind that recycling is increasing every year as an alternative of the scarcity of this precious metal. In fact, in 2016, the amount of cobalt recycled was $30 \%$ compared with the total consumed [4]. Cobalt is obtained as a by-product in mining industry, mainly in Congo, from nickel and copper ores. Moreover, this activity is involved in violence, and labor rights are violated [5].

There is a wide range of technologies that allow achieving the reduction of water pollutants, such as ion exchange, extraction with solvents, adsorption, and nanofiltration. Adsorption is considered the best option in order to overcome this problem since this method is suitable for the removal of heavy metals from water 
solutions and it is relatively cheap, depending on the price of the adsorbent. Consequently, in bibliography, a large number of materials have been considered as potential metal adsorbents in aqueous solutions. First of all, clinoptilolite has shown good capacity to adsorb $\mathrm{Cu}^{2+}, \mathrm{Cr}^{3+}$, and $\mathrm{Fe}^{3+}$, removing $95 \%, 96 \%$, and $85 \%$, respectively, at $\mathrm{pH}$ 6 [6]. Furthermore, spherical mesoporous silica adsorbed the $\mathrm{Cu}^{2+}$ and $\mathrm{Cd}^{2+}$ in water solution, $80 \%$ and $20 \%$, respectively [7]. Mohammed and Sahum studied the adsorption of $\mathrm{Cr}^{3+}$ from aqueous solutions using eucalyptus bark, removing $99 \%$ of the $\mathrm{Cr}^{3+}$ in water solution [8]. As for carbonaceous materials, activated carbon from coconut coir pith has shown a good cadmium adsorption from a solution of $40 \mathrm{mg} / \mathrm{L}$ at pH 5 [9]. Among all these materials, carbonaceous materials are good adsorbents, even they are especially useful because of their high surface area and chemical surface.

Some activated carbons contain a great deal of oxygenated groups: phenolic, carboxyl, and carbonyl, which promote the adsorption phenomena, due to the fact that they increase the negative charge density of the adsorbent surface. The main characteristic feature of this sort of material is their porous and disorganized structure, which contributes to their high specific surface [1]. Nevertheless, the dominance of micropores (pore sizes lower than $20 \AA$ ) in their structure increases material diffusion resistance, which hinders the adsorption process. However, some carbonaceous materials such as carbon nanotubes and ordered mesoporous carbons overcome this obstacle [10]. For instance, ordered mesoporous carbons have both uniform and large pore sizes, which endue them with large pore volumes; consequently, they are used for many applications, including adsorption. In fact, some studies have shown good effectivity for metal adsorption. Barczak et al. studied the adsorption of zinc, lead, copper, and cadmium on ordered mesoporous carbons obtaining fast adsorption rates and high adsorption capacities around 30 and $180 \mathrm{mg} / \mathrm{g}$ for zinc and lead, respectively. As for the recovery of the metal ions previously adsorbed, the use of acid solutions, such as $\mathrm{HCl}$ or $\mathrm{HNO}_{3}$, was effective, recovering $40 \%$ of the zinc adsorbed previously and all the adsorbed lead [10]. Also, ordered mesoporous carbons allow their organic functionalization by oxidation, which causes an increase of oxygenated groups on the adsorbent surface, promoting the adsorption capacity of this material [11].

Also, operating conditions such as initial solution $\mathrm{pH}$, adsorbent dosage, foreign ions, $\left(\mathrm{Na}^{+}\right.$presence), particle size, contact time, and temperature must be considered. In some cases, it could inhibit the adsorption process depending on the mechanism of adsorption that prevails. In the case of adsorption using graphene oxide, the solution $\mathrm{pH}$ is recognized as a very influential parameter that dominates the adsorption process, which not only governs the species of heavy metal ions present in the solution but also affects the surface potential of the adsorbent. Besides, presence of foreign ions $\left(\mathrm{Na}^{+}\right.$cations) also affects the heavy metal ions adsorption process since these additional ions compete for the limited reactive sites [12]. For instance, the $\mathrm{Cd}^{2+}$ adsorption on coconut coir pith carbon increases $40 \%$ from $\mathrm{pH}$
2 to $\mathrm{pH} 6$ [9]. Regarding the temperature influence, it depends on the kind of adsorption and whether the adsorption is exothermic or endothermic. For instance, the adsorption of methylene blue on activated carbon highly increases from 276 to $444 \mathrm{mg} \cdot \mathrm{g}^{-1}$ when the temperature increases from 30 to $60^{\circ} \mathrm{C}$ since it is an endothermic process, typical of chemisorptions [13].

With regard to obtaining metallic cobalt from water solutions, as well as all strategic metals, it depends on its concentration in the water steam. Some of the implemented methodologies are solvent extraction, cementation, and electrochemical treatment. All of them are quite complex; not only do they affect the environment but also they involve many combined operations. Thus, a simpler and efficient recovery process linked to a commercial application needs to be studied $[14,15]$.

Adsorption processes are considered the best option to overcome this problem since this method is suitable to preconcentrate metal ions, which were initially in trace amounts in the water steam, in order to facilitate its recovery by other technologies, such as electrochemical treatment and solvent extraction. Moreover, adsorption is a suitable technology to preconcentrate metal ions in water solutions to facilitate its recovery by other techniques that are implemented in industrial scale, which are more complex and expensive [16]. Wu et al. [11] evaluated the regeneration of mesoporous carbons, by using acid solutions such as $\mathrm{HCl}$ and $\mathrm{HNO}_{3}$. This methodology allows recovering around $40 \%$ of the previously adsorbed $\mathrm{Zn}^{2+}$ and all the adsorbed $\mathrm{Pb}^{2+}$. The adsorption capacity of the material after successive adsorption cycles hardly changes [11]. Suryavanshi and Shukla [17] studied the capacity of gallium adsorption on oxidized coir and its recovery. The regeneration tests were performed with $\mathrm{HCl}$ solutions, varying the acid concentration in the regenerative solution between 0.1 and $1.0 \mathrm{M}$. They found that the higher the acid concentration, the higher the gallium amount recovered, even with a rate of 78.3 and $98.6 \%$ using an acid concentration of 0.1 and $1.0 \mathrm{M}$, respectively.

The novelty of this research is the use of adsorption as a tool to preconcentrate cobalt for its recovery by solvent extraction or electrochemical treatment. Compared with previous studies of our research group, this paper focuses on the influence of adsorption conditions and the recovery of cobalt ions [18]. This could provide a wide range of options to overcome the high complexity of the recovery process of strategic metals from mining waste waters.

\section{Materials and Methods}

2.1. Materials. Silica gel $\left(\mathrm{SiO}_{2}, \geq 99 \%\right)$ of $60 \AA$ and $40-63 \mu \mathrm{m}$ particle size, sucrose $\left(\mathrm{C}_{12} \mathrm{H}_{22} \mathrm{O}_{11}, 99.5 \%\right)$, hydrofluoric acid (HF, $40 \%)$, and cobalt (II) nitrate hexahydrate $\left(\mathrm{Co}\left(\mathrm{NO}_{3}\right)_{2}\right.$ $\geq 98 \%$ ) were supplied by Sigma Aldrich. Hydrofluoric acid (HF, 40\%) was provided by Sigma Aldrich, nitric acid $\left(\mathrm{HNO}_{3}, 69.5 \%\right)$ was provided by Carlo Erba, and sulphuric acid $\left(\mathrm{H}_{2} \mathrm{SO}_{4}, 98 \%\right)$ was provided by Panreac Company. Finally, sodium chloride $(\mathrm{NaCl}, 99.5 \%)$ was purchased 
from Fluka, and potassium phosphate monobasic $\left(\mathrm{KH}_{2} \mathrm{PO}_{3}, 99 \%\right)$ and potassium phosphate dibasic $\left(\mathrm{K}_{2} \mathrm{HPO}_{3}, 99 \%\right)$ were supplied by PROBUS. Ultrapure water was used throughout.

2.2. Mesoporous Activated Carbon Synthesis. The synthesis of the adsorbent studied (MCSG60A) was performed following the replica method, as previous works, using sucrose as the carbon source and silica gel $(60 \AA)$ as the template. Firstly, silica gel was impregnated with sucrose in an acid aqueous solution which contains sulphuric acid $\left(\mathrm{H}_{2} \mathrm{SO}_{4}\right)$. Afterwards, this mixture was precarbonized to $100^{\circ} \mathrm{C}$ for $6 \mathrm{~h}$ and then up to $150^{\circ} \mathrm{C}$ for another $6 \mathrm{~h}$. Later, the material was further heated at $800^{\circ} \mathrm{C}$ in $\mathrm{N}_{2}$ atmosphere during $240 \mathrm{~min}$. Finally, the silica gel template was removed using an aqueous solution of hydrofluoric acid (HF, 25 wt.\%). Later, the material was washed with ethanol and deionised water [18].

With regard to its functionalization (activation), the mesoporous carbons were heated to $450^{\circ} \mathrm{C}$ under inert atmosphere at $10^{\circ} \mathrm{C} / \mathrm{min}$ which consists in a nitrogen stream of $100 \mathrm{~mL} / \mathrm{min}$ of $\mathrm{N}_{2}$. The materials were activated in mild oxidant atmosphere (oxygen diluted at $5 \%$ in nitrogen), with a flow of $100 \mathrm{~mL} / \mathrm{min}$, for 5 hours at $450^{\circ} \mathrm{C}$ [19].

2.3. Characterization of the Materials. Firstly, the superficial chemistry of the adsorbent has been tested by its infrared spectrum (400 and $4,000 \mathrm{~cm}^{-1}$ ) using a Thermo Nicolet, Avatar 360 FT-IR spectrophotometer. Zeta potential measurements were performed using a MALVERN Zetasizer Nano Series nano $Z$ apparatus. During the essays, $50 \mathrm{mg}$ of the sample was diluted in $20 \mathrm{~mL}$ of milli-Q water and the $\mathrm{pH}$ was adjusted with solutions of $1.0,0.1$, and $0.01 \mathrm{M}$ of either $\mathrm{HCl}$ or $\mathrm{NaOH}$.

In order to characterize the textural properties of the adsorbent, it was evaluated by means of nitrogen adsorption-desorption isotherms at $-196^{\circ} \mathrm{C}$, using a Micromeritics ASAP-2020 adsorption apparatus. The micropore volume $\left(V_{\text {micro }}\right)$ and mesoporous surface $\left(S_{\text {meso }}\right)$ were obtained using the t-plot method. The total surface area $\left(S_{\mathrm{BET}}\right)$ and the pore volume $\left(V_{\text {total }}\right)$ were determined using the BET (Brunauer-Emmett-Teller) equation and the single point method. Pore size distribution (PSD) curves were calculated by the BJH (Barrett-Joyner-Halenda) method with the KJS (Kruk-Jaroniec-Sayari) correction.

2.4. Adsorption Experiments. The adsorption experiments were carried out in the batch mode, in $2 \mathrm{~mL}$ Eppendorf tubes, in orbital agitation using a Thermomixer Comfort apparatus equipped with temperature control. The experimental procedure is as follows: Tests were performed by adding the appropriate dosage of the carbonaceous adsorbent to $2 \mathrm{~mL}$ of a $\mathrm{Co}\left(\mathrm{NO}_{3}\right)_{2}$ aqueous solution with the desired amount of $\mathrm{Co}^{2+}$. After each experiment, the adsorbent was separated from the aqueous solution by centrifugation $(10,900 \mathrm{rpm})$, using a Spectrafuge $24 \mathrm{D}$ apparatus from Labnet International. The cobalt concentration in water was measured by atomic absorption spectroscopy (AAS), by means of an AA-7000 Shimadzu equipment [18].

The kinetic adsorption curves were determined by measuring the $\mathrm{Co}^{2+}$ concentration in the solution at different times during the adsorption process. Each point of the curve was measured in triplicate. The adsorption capacity of the adsorbent was calculated with equation (1) and the percentage of cobalt removed with equation (2).

$$
\begin{aligned}
q & =\frac{\left(C_{0}-C\right) \cdot V}{m}, \\
\% \mathrm{Co}^{2+} \text { Adsorbed } & =\frac{\left(C_{0}-C\right)}{C_{0}} \cdot 100,
\end{aligned}
$$

where $q(\mathrm{mg} / \mathrm{g})$ is the amount of $\mathrm{Co}^{2+}$ adsorbed per gram of the adsorbent; $C_{0}$ and $C(\mathrm{mg} / \mathrm{L})$ are the concentrations of $\mathrm{Co}^{2+}$ in the aqueous phase before and after adsorption, respectively; $m$ (g) is the weight of the adsorbent, and $V(\mathrm{~L})$ is the volume of the aqueous phase.

\section{Results and Discussion}

The influence of operating conditions has been studied following the previous methodology and changing a definite variable.

3.1. Kinetics. The optimization of the operation time is very important in order to minimize costs and energy. The adsorption kinetic results are represented in Figure 1. This figure shows the evolution of cobalt removal (\%) with time.

The cobalt adsorption process on MCSG60A showed a cobalt removal of $85-90 \%$ in only 15 minutes, with an equilibrium adsorption capacity of $1.5 \mathrm{mg} / \mathrm{g}$. Moreover, experiments of 4 days of adsorption time displayed that $86 \%$ of the cobalt in the solution has been adsorbed; as a result, the activated carbon does not adsorb more cobalt despite increasing the contact time. The high adsorption rate was mainly due to the porous size distribution of the adsorbent because, as the BET analysis (Table 1) indicates, the carbon possesses a large specific surface area with a noticeable mesoporous surface.

Consider that the size of hydrated ion will determine which ions will be able to pass through the adsorbent pores. In this sense, the average pore size of the adsorbent MCSGG60A is much larger $(60 \AA)$ than the cobalt solvatation shell size (diameter $8.5 \AA$ for $\left[\mathrm{Co}\left(\mathrm{H}_{2} \mathrm{O}\right)_{6}\right]^{2+}$ ) [20]. Table 1 shows the textural properties of the adsorbent. Figure 2 shows SEM images of MCSG60A adsorbent.

On the other hand, the large equilibrium adsorption capacity on the mesoporous carbons was due to the high negative charge density of the surface, as a consequence of the presence of a large number of oxygenated groups $(\mathrm{COOH}, \mathrm{C}=\mathrm{O}, \mathrm{O}-\mathrm{H}$, etc.); this fact was observed in the FTIR analysis (Figure 3 ). The $Z$ potential analysis also shows that the surface of the carbon remains negatively charged at $\mathrm{pH}$ values higher than 2.3. 


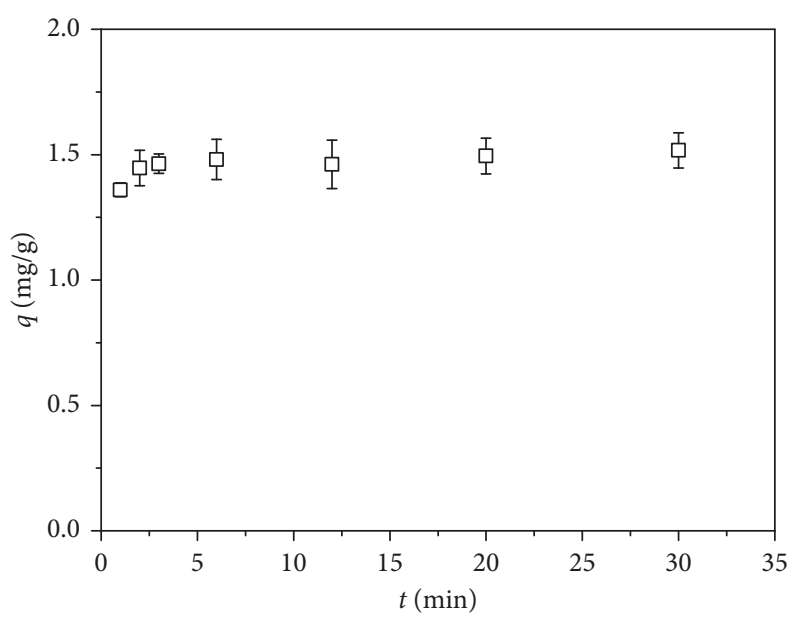

$\square$ MCSG60A

Figure 1: Cobalt adsorption kinetic on synthetized MCSG60A. Conditions: $\left[\mathrm{Co}^{2+}\right]=20 \mathrm{mg} / \mathrm{L}, T=25^{\circ} \mathrm{C}$, adsorbent dosage $=12.5 \mathrm{~g} / \mathrm{L}, \mathrm{pH}=6$, and $1100 \mathrm{rpm}$.

TABle 1: Textural properties of MCSG60A.

\begin{tabular}{cccccc}
\hline & $S_{\text {BET }}\left(\mathrm{m}^{2} / \mathrm{g}\right)$ & $S_{\text {meso }}\left(\mathrm{m}^{2} / \mathrm{g}\right)$ & $D_{\text {pore }}(\AA)$ & $V_{\text {meso }}\left(\mathrm{cm}^{3} / \mathrm{g}\right)$ & $V_{\text {total }}\left(\mathrm{cm}^{3} / \mathrm{g}\right)$ \\
\hline MCSG60A & 911 & 753 & 60 & 1.05 & 1.12 \\
\hline
\end{tabular}

$D_{\text {pore }}=$ average pore size; $V_{\text {meso }}=V_{\text {total }}-V_{\text {micro }}$.

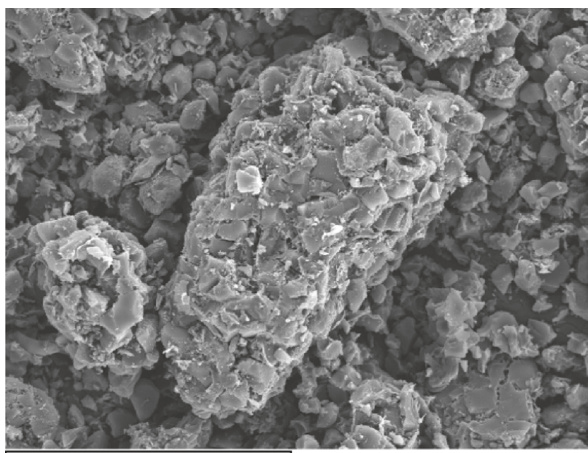

$500 \mu \mathrm{m}$

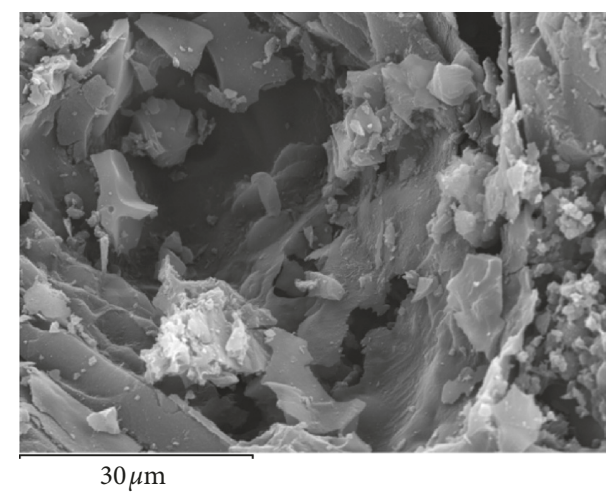

(b)

(a)

Figure 2: SEM images of MCSG60A.

3.2. Adsorbent Dosage Influence. Figure 4 shows the influence of the adsorbent dosage on equilibrium adsorption capacity and on cobalt removal. The initial concentration of $\mathrm{Co}^{2+}$ has been changed to $50 \mathrm{mg} / \mathrm{L}$ instead of $20 \mathrm{mg} / \mathrm{L}$ to distinguish better the differences among each test.

The percentage of $\mathrm{Co}^{2+}$ adsorbed from the solution increases with the dosage, until a certain dosage value $(15.0 \mathrm{~g} / \mathrm{L})$, from which the amount of $\mathrm{Co}^{2+}$ adsorbed tends to remain constant $(2.0 \mathrm{mg} / \mathrm{g})$. Regarding the equilibrium capacity, it tends to diminish with the adsorbent dosage; this fact may be due to the overlapping or aggregation of the adsorbent particles, which leads to a decrease in the available adsorbent surface area and an increase in the diffusional resistances. Moreover, heavy metal ions can rapidly induce aggregation/folding by the strong interaction between them and carboxyl groups [12].
3.3. Temperature Influence (Thermodynamic Study). The influence of temperature on equilibrium adsorption capacity and on cobalt removal appears in Figure 5.

As Figure 5 shows, the effect of temperature on the adsorption process is almost negligible. In all the ranges of temperature studied, its equilibrium capacity remains constant $(1.4 \mathrm{mg} / \mathrm{g})$ since the capacity decreases very slightly (less than $2 \%$ ), at high temperatures. So, to make a deep analysis, the thermodynamics parameters were determined. The change in the standard enthalpy $\left(\Delta H^{0}(\mathrm{~kJ} /\right.$ $\mathrm{mol}))$ and entropy $\left(\Delta S^{0},(\mathrm{~J} / \mathrm{mol} \cdot \mathrm{K})\right)$ was calculated with the Van't Hoff expression (equation (6)), which is developed by equations (4) and (5). Gibbs free energy $\left(\Delta G^{0}(\mathrm{~kJ} / \mathrm{mol})\right)$ is estimated with equations (3) and (4). In these equations, $K c$ is the equilibrium constant, $C_{0}(\mathrm{mg} / \mathrm{L})$ is the initial concentration of $\mathrm{Co}^{2+}, C_{\mathrm{e}}(\mathrm{mg} / \mathrm{L})$ is the concentration at 


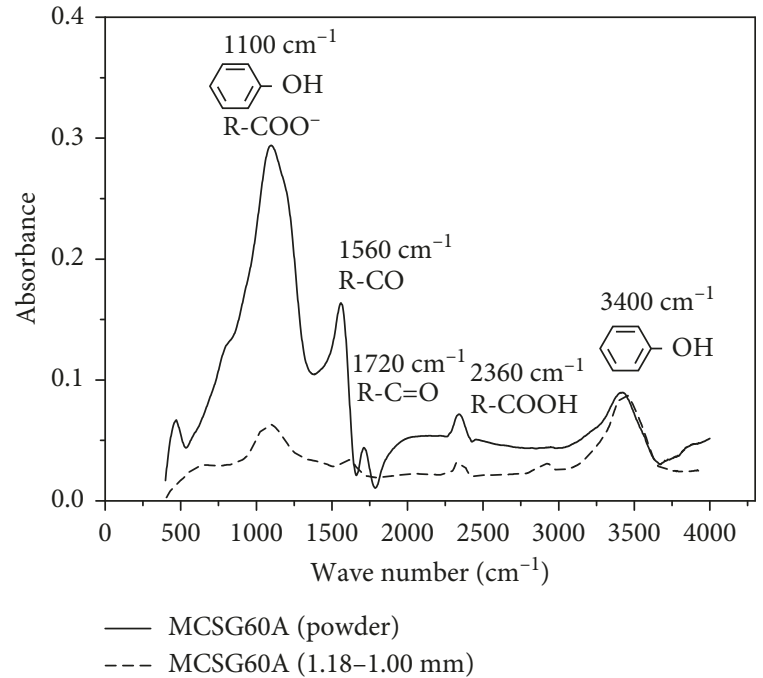

FIGURe 3: FT-IR analysis for MCSG60A with two different particle sizes.

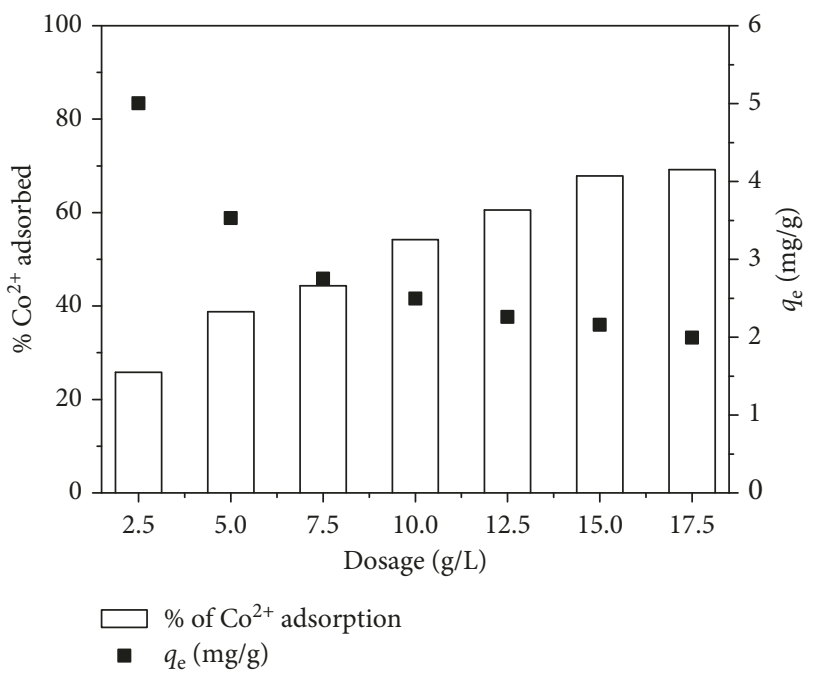

FIGURE 4: Effect of the adsorbent dosage on cobalt adsorption using MCSG60A. Conditions: $\left[\mathrm{Co}^{2+}\right]=50 \mathrm{mg} / \mathrm{L}$, time $=3$ hours, $T=25^{\circ} \mathrm{C}$, particle size $=$ powder, $\mathrm{pH}=6$, and $1100 \mathrm{rpm}$.

equilibrium, $T(\mathrm{~K})$ is the temperature, and $R$ is the universal gas constant $(8.134 \mathrm{~J} / \mathrm{K} \cdot \mathrm{mol})$. The thermodynamic results appear in Table 2 . In addition, the fitting of the equation (6) for experimental data is represented in Figure 6.

$$
\begin{aligned}
K_{\mathrm{C}} & =\frac{C_{0}-C_{\mathrm{e}}}{C_{\mathrm{e}}}, \\
\Delta G^{0} & =-R \cdot T \cdot \ln K_{\mathrm{C}}, \\
\Delta G^{0} & =\Delta H^{0}-T \cdot \Delta S^{0}, \\
-\ln \left(K_{\mathrm{C}}\right) & =\left(\frac{\Delta H^{0}}{R}\right) \cdot \frac{1}{T}-\frac{\Delta S^{0}}{R} .
\end{aligned}
$$

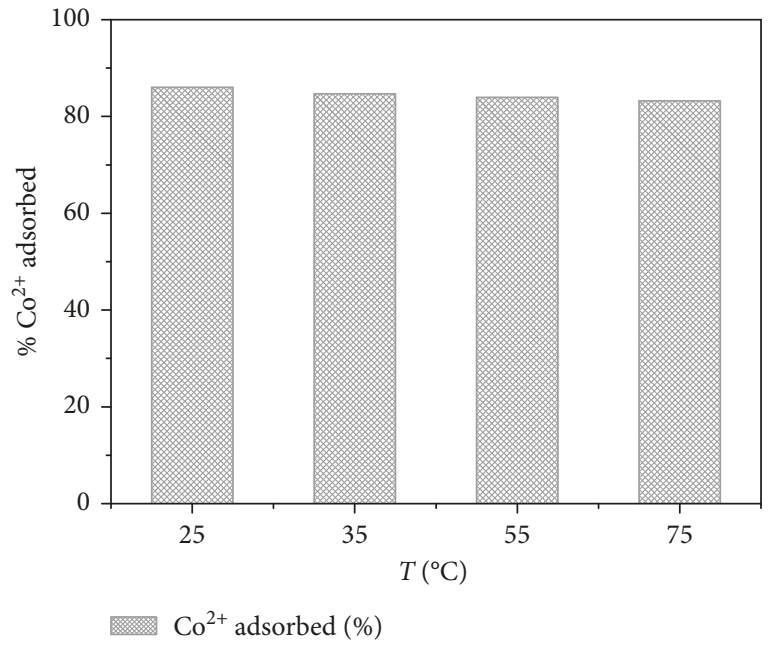

FIgURE 5: Effect of the temperature on cobalt adsorption using MCSG60A. Conditions: $\left[\mathrm{Co}^{2+}\right]=20 \mathrm{mg} / \mathrm{L}$, particle size $=$ powder, $\mathrm{pH}=6$, adsorbent dosage $=12.5 \mathrm{~g} / \mathrm{L}$, and $1100 \mathrm{rpm}$.

TABLE 2: Thermodynamic analysis of the cobalt adsorption on MCSG60A.

\begin{tabular}{lcccc}
\hline$T(\mathrm{~K})$ & $K_{\mathrm{C}}$ & $\Delta G^{0}(\mathrm{~kJ} / \mathrm{mol})$ & $\Delta H^{0}(\mathrm{~kJ} / \mathrm{mol})$ & $\Delta S^{0}(\mathrm{~J} / \mathrm{K} \cdot \mathrm{mol})$ \\
\hline 298 & 7.9 & -5.0 & & \\
308 & 7.8 & -5.1 & -4.57 & 1.98 \\
328 & 6.9 & -5.1 & & \\
348 & 6.1 & -5.1 & & \\
\hline$R^{2}=0.96$ & & &
\end{tabular}

$R^{2}=0.96$

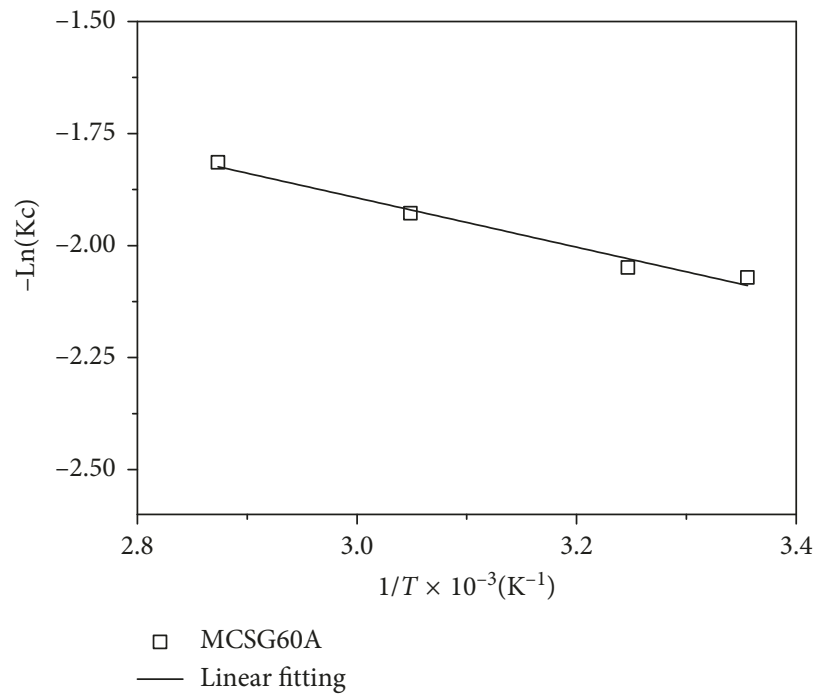

Figure 6: Experiment data fitting of equation 6.

$\Delta H^{0}$ and $\Delta G^{0}$ are below zero; as a result, the adsorption is an exothermic process. The typical range of enthalpy values for chemisorption is between -80 and $-450 \mathrm{~kJ} / \mathrm{mol}$. However, the fact that in the present study the enthalpy value is $-4.57 \mathrm{~kJ} / \mathrm{mol}$ indicates that physisorption is the only adsorption mechanism. This kind of adsorption is mainly attributed to electrostatic interactions. This is corroborated 
by the $\Delta G^{0}$ value, which is $-5.1 \mathrm{KJ} / \mathrm{mol}$, inside the range between 0 and $-20 \mathrm{~kJ} / \mathrm{mol}$, proving that cobalt get adsorbed on MCSG60A by physisorption phenomena [21].

Regarding the entropy, its positive $\Delta S^{0}$ suggests an increase of the randomness, which involves some structural changes in the adsorbate-adsorbent interface. The adsorbed molecules, which were displaced by the surface groups of the adsorbate, gained more translational entropy than the amount, which was lost by the adsorbate molecules [22].

3.4. Particle Size Influence. For the particle size influence, the activated carbon has been sieved following the standard ISO3310.1. The following sizes have been studied: $1.18-1.00$, $0.80-0.76$, and $0.71-0.56 \mathrm{~mm}$. Figure 7 shows $\mathrm{Co}^{2+}$ adsorption isotherms obtained with different particle size of the adsorbent.

As Figure 7 shows, the higher the particle size, the lower the adsorption capacity. This variable affects the adsorption process to the point that the adsorption capacity decreases by $18 \%$. This could be explained by the fact that larger particle sizes offer lower contact surface between adsorbent and adsorbate, which causes a reduction of the superficial groups that could interact with the $\mathrm{Co}^{2+}$ of the solution [23]. To further analyze, FT-IR analysis was carried out with two different particle sizes of MCSG60A (Figure 3). In general, the mesoporous carbons showed carboxyl and phenolic groups; nevertheless, if the particle size is high, the presence of these groups decreases considerably. This is due to the activation process, when the particle is big; the activation is only produced in the external area of the solid, due to internal material diffusion resistance. On the other hand, for smaller particles, the most part of its surface is activated.

3.5. Agitation Speed Influence. Figure 8 shows $\mathrm{Co}^{2+}$ adsorption isotherms obtained with different stirring rates.

An increment in the stirring speed causes an increase in the adsorption capacity of the adsorbent because when stirring speed is high, the external material diffusion is promoted. As can be observed in Figure 8, at $300 \mathrm{rpm}$, the capacity decreases by $13 \%$ compared with the optimum agitation speed $(1100 \mathrm{rpm})$. However, when the stirring speed is increased above $1100 \mathrm{rpm}$, the capacity remains constant indicating that the external mass transfer resistance is negligible. Thus, $1100 \mathrm{rpm}$ is the optimum stirring speed. An increase in the agitation degree involves an increase in the mobility of the system. As a result, the faster the stirrer rotates, the lower the external mass transfer resistance is, which causes an enhancement in the adsorption capacity.

3.6. Foreign Ions/Ionic Strength Influence. In the study of the ionic strength, $\mathrm{NaCl}$ has been used to adjust the desired values of this variable since this dissociates to $\mathrm{Na}^{+}$cations and $\mathrm{Cl}^{-}$anions. It is calculated by the following expression:

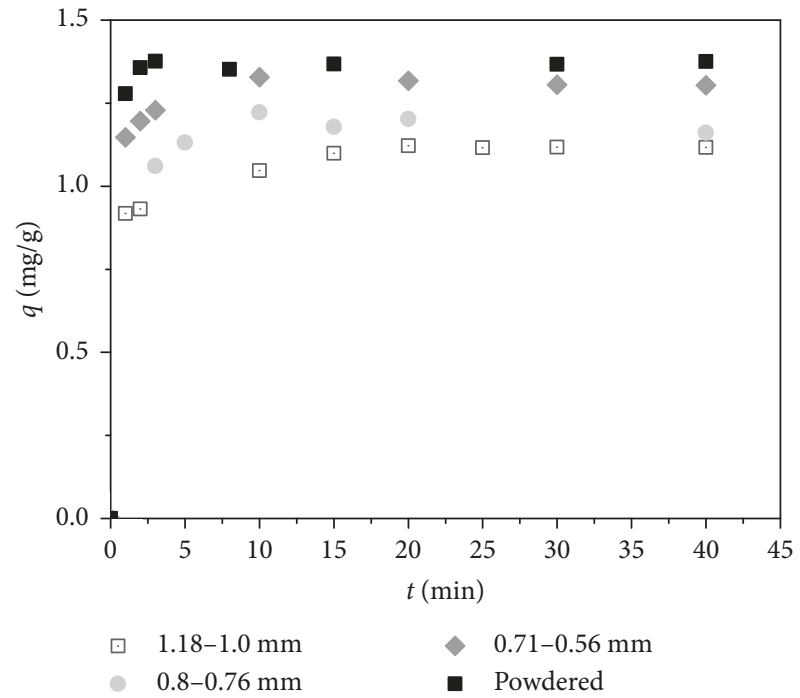

Figure 7: Effect of the particular size on cobalt adsorption using MCSG60A. Conditions: $\left[\mathrm{Co}^{2+}\right]=20 \mathrm{mg} / \mathrm{L}, T=25^{\circ} \mathrm{C}, \mathrm{pH}=6$, adsorbent dosage $=12.5 \mathrm{~g} / \mathrm{L}$, and $1100 \mathrm{rpm}$.

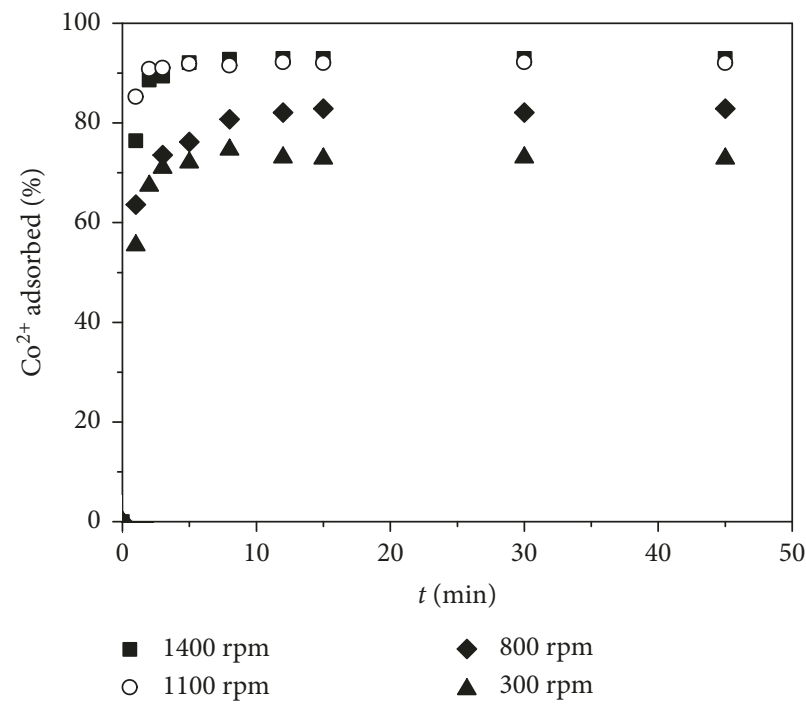

FIGURE 8: Effect of the agitation speed on cobalt adsorption using MCSG60A. Conditions: $\left[\mathrm{Co}^{2+}\right]=20 \mathrm{mg} / \mathrm{L}, T=25^{\circ} \mathrm{C}, \mathrm{pH}=6$, adsorbent dosage $=12.5 \mathrm{~g} / \mathrm{L}$, and particle size $=$ powder.

$$
\mathrm{FI}=\frac{1}{2} \cdot \sum\left(C_{\mathrm{i}} \cdot Z_{\mathrm{i}}^{2}\right)
$$

where $C_{\mathrm{i}}(\mathrm{mg} / \mathrm{g})$ is the concentration of the ion species $\mathrm{i}, Z_{\mathrm{i}}$ is their charges, and FI (mM) is the ionic strength of the total solution. The results of the influence of the ionic strength using $\mathrm{NaCl}$, on the cobalt adsorption, are shown in Figure 9.

As Figure 9 shows, the ionic strength affects negatively the cobalt adsorption on MCSG60A, decreasing the capacity by $60 \%$ when the ionic strength is $96 \mathrm{mM}$, due to the presence of $\mathrm{Na}^{+}$. This is explained by the fact that $\mathrm{Na}^{+}$ions would compete with metal ions for the adsorption sites, depending on their relative affinities. Considering this, the decrease on its adsorption is a consequence of the competition between $\mathrm{Co}^{2+}$ 


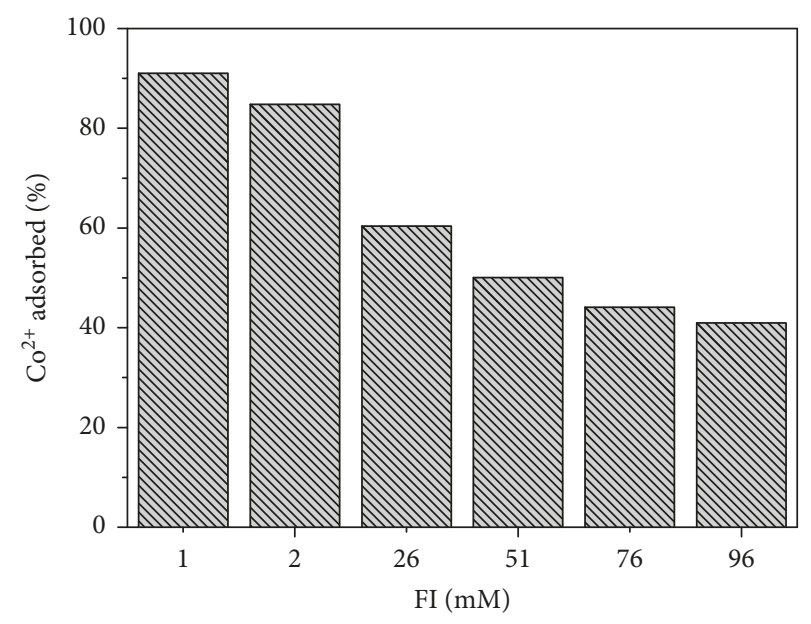

MIIV MCSG60A

Figure 9: Effect of the ionic strength on cobalt adsorption using MCSG60A $\left[\mathrm{Co}^{2+}\right]=20 \mathrm{mg} / \mathrm{L}, T=25^{\circ} \mathrm{C}$, adsorbent dosage $=10 \mathrm{~g} / \mathrm{L}$, particle size $=$ powder, and $1100 \mathrm{rpm}$.

and $\mathrm{Na}^{+}$. Thus, the adsorption on MCSG60A is not selective. In fact, this is a characteristic of physisorcion processes. Furthermore, ionic strength can affect the electrostatic interactions, as well as limit the ions transfer from the solution to the surface of the adsorbent [12]. Thus, the adsorption process is mainly due to electrostatic interactions, as concluded in the previous thermodynamic study. These results agree with metal adsorption studies carried out with carbonaceous materials; for instance, Tan and his research group obtained that the adsorption of $\mathrm{Cd}^{2+}, \mathrm{Ni}^{2+}$, and $\mathrm{Cu}^{2+}$ on graphene oxide was slightly impeded with the increasing presence of $\mathrm{Na}^{+}$, decreasing its adsorption capacity to 8,11 , and $11 \%$, respectively [24]. Regarding the $\mathrm{pH}$ evolution of the ionic strength influence, there is nothing to outline. In all cases, the $\mathrm{pH}$ decreases to $\mathrm{pH} 3.0-3.5$; the only difference is that the initial $\mathrm{pH}$ increases with the presence of $\mathrm{NaCl}$, i.e., 6.5 with an initial $\mathrm{NaCl}$ concentration of $1 \mathrm{mM}$ and 7.0 at $95 \mathrm{mM}$.

3.7. $\mathrm{pH}$ Influence. The $\mathrm{pH}$ of the solution plays an important role in the adsorption process and particularly in the uptake capacity. For this reason, the adsorption of $\mathrm{Co}^{2+}$ on MCSG60A was studied varying the initial $\mathrm{pH}$ from 2 to 8 , considering the speciation diagram of cobalt as reference. According to this diagram, at $\mathrm{pH}$ values higher than 8 , cobalt tends to precipitate in the form of cobalt hydroxide $\left(\mathrm{Co}(\mathrm{OH})_{2}\right)$ [23].

Two different sets of experiments were carried out: a first group in which the $\mathrm{pH}$ was set free and a second one in which the $\mathrm{pH}$ was kept constant during the whole process by means of a buffer solution.

Figure 10 shows the results obtained with different initial $\mathrm{pH}$ values, without controlling this variable throughout the experiment. Table 3 consists in the $\mathrm{pH}$ evolution in each one of the adsorption experiments.

As Table 3 shows, during the adsorption process, the $\mathrm{pH}$ decreases considerably from 5.6 to 3.2. However, this effect decreases in acid solutions. If the initial $\mathrm{pH}$ is higher than

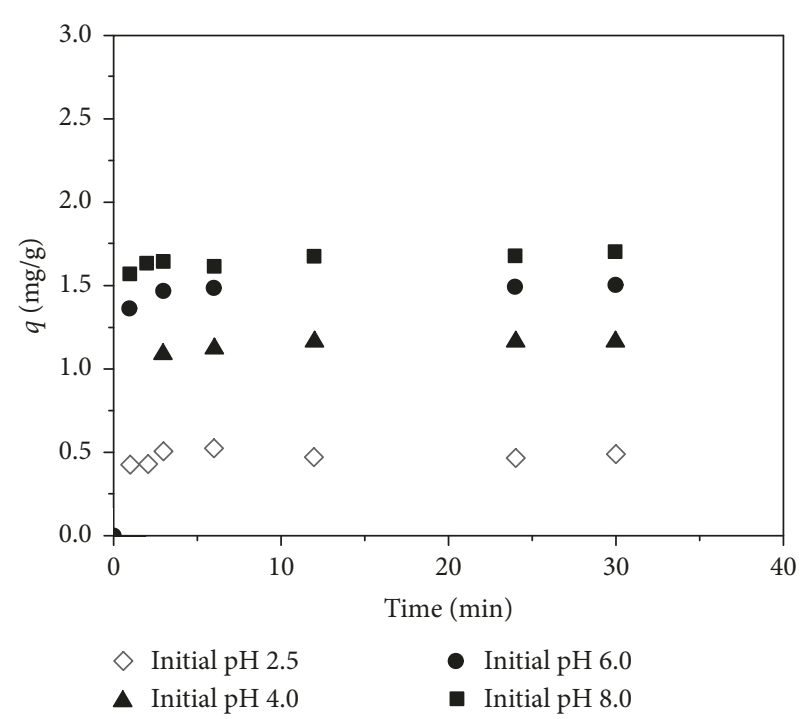

FIgURE 10: Effect of the initial $\mathrm{pH}$ on cobalt adsorption using MCSG60A. Conditions: $\left[\mathrm{Co}^{2+}\right]=20 \mathrm{mg} / \mathrm{L}, T=25^{\circ} \mathrm{C}$, adsorbent dosage $=12.5 \mathrm{~g} / \mathrm{L}$, particle size $=$ powder, and $1100 \mathrm{rpm}$.

TABLE 3: Result of the $\mathrm{pH}$ evolution during the $\mathrm{Co}^{2+}$ adsorption experiments.

\begin{tabular}{lc}
\hline $\mathrm{pH}$ initial & $\mathrm{pH}$ final \\
\hline 2.5 & 2.5 \\
4.1 & 3.2 \\
6.0 & 3.3 \\
8.0 & 3.5 \\
\hline
\end{tabular}

4.0, the final $\mathrm{pH}$ is between 3.2 and 3.5. For instance, at initial $\mathrm{pH} 2.5$, the $\mathrm{pH}$ remains steady during the process. This could be due to the presence of some groups, such as phenolic groups in the adsorbent surface that acidify the media without exchange process.

According to Figure 10, the capacity decreases by $70 \%$ when the initial $\mathrm{pH}$ is varied from 8 to 2 . Thus, the $\mathrm{Co}^{2+}$ adsorption on MCSG60A is highly $\mathrm{pH}$ dependent. This can be explained in terms of isoelectric point $\left(\mathrm{pH}_{\mathrm{IEP}}\right)$ and how the surface charge of the solid changes with this value, as well as considering that electrostatic forces are the main responsible of the adsorption process. According to the potential $Z$ analysis, if the $\mathrm{pH}$ is lower than $\mathrm{pH}_{\mathrm{IEP}}$, which is 2.3, the surface of the carbon is positively charged; as a result, it loses its capacity to retain $\mathrm{Co}^{2+}$. On the other hand, above $\mathrm{pH}_{\text {IEP }}$ (2.3), the surface is negatively charged. Thus, an increase in the initial $\mathrm{pH}$ solution will lead to more negatively charged sites, promoting the adsorption of $\mathrm{Co}^{2+}$ [23]. Despite the fact that cobalt adsorption on MCSG60A is mainly physical, it has to be considered that its superficial chemistry is complex (Figure 3 ). Thus, another reason that justifies the observed effect of the $\mathrm{pH}$ on the adsorption could be the suppression of the complexation. In acid solutions, some functional groups of the surface are protonated and in these conditions, it is difficult to dissociate them; as a result, the complexation between cobalt ions and these groups is suppressed [12]. 
To further analyze this phenomenon, the $\mathrm{pH}$ evolution of a solution of $\mathrm{Co}^{2+}$ and of pure water was measured, using MCSG60A. Both experiments were carried out at $\mathrm{pH} 6$, $T=25^{\circ} \mathrm{C}$, adsorbent dosage $=12.5 \mathrm{~g} / \mathrm{L}$, particle size $=$ powder, $1100 \mathrm{rpm}$, and $\left[\mathrm{Co}^{2+}\right]=20 \mathrm{mg} / \mathrm{L}$ for the cobalt solution.

The studies showed that the $\mathrm{pH}$ changes even without adsorption process (when the solid is dispersed in water), changing its $\mathrm{pH}$ from 6.6 to 3.6. This change is similar to the studies in presence of $\mathrm{Co}^{2+}$, in which the $\mathrm{pH}$ of the media changes from 6.0 to 3.3. As a consequence, the synthesized carbon MCSG60A causes the acidification of the media, this could be due to the presence of phenolic and carboxylic groups on the solid surface. This kind of groups release $\mathrm{H}^{+}$in water solution, without adsorption process [25].

The study at controlled $\mathrm{pH}$ was carried out using a phosphate buffer solution $\left(\mathrm{K}_{2} \mathrm{HPO}_{4} / \mathrm{KH}_{2} \mathrm{PO}_{4}\right)$. This solution consists of a mixture of monobasic dihydrogen phosphate and dibasic monohydrogen phosphate. By varying the amount of each salt, a range of buffers can be prepared. In this case, with a mixture of $8.5 \mathrm{~mL}$ of $\mathrm{K}_{2} \mathrm{HPO}_{4} 1 \mathrm{M}$ and $91.5 \mathrm{~mL}$ of $\mathrm{KH}_{2} \mathrm{PO}_{4} 1 \mathrm{M}$, it is possible to buffer well at $\mathrm{pH} 6$. Figure 11 shows the results obtained with different initial $\mathrm{pH}$ values, controlling this variable throughout the experiment by means of buffer solutions. The initial $\mathrm{pH}$ and final $\mathrm{pH}$ are 5.8 and 5.6, respectively; as a result, it could be considered a buffered assay.

As can be observed in Figure 11, when the $\mathrm{pH}$ is controlled, the adsorption capacity does not vary when compared with the free $\mathrm{pH}$ test, despite the negative effect of the ion strength associated to the buffer solution (91 mM). Controlled $\mathrm{pH}$ also makes the cobalt adsorption even faster, reaching equilibrium in 3 minutes. The cause could be its superficial charge, which is negative, according to zeta potential results, as previously shown in Figure 3. This negative charge maintains with the $\mathrm{pH}$ controlling, keeping the driving force between the positive ions of cobalt and the negative surface of the activated carbon. Besides, if the $\mathrm{pH}$ remains constant, the groups on its surface remain protonated. On the other hand, when the ionic strength rises but without controlled $\mathrm{pH}$, its capacity decreases more than a half compared with the $\mathrm{pH}$ controlled adsorption. This proves that the adsorption process is mainly due to electrostatic interactions between adsorbate and adsorbent. The only alternative to promote the adsorption in solutions with high ionic strength is controlling the solution $\mathrm{pH}$.

\section{Regeneration Studies}

In order to study the reuse of MCSG60A and preconcentrate cobalt in the water steam, after the adsorption assays, the adsorbent was immersed in acid media. The acid solutions tested where HF ( $\mathrm{pH}$ 1.5) recirculated from the synthesis step and $\mathrm{HNO}_{3}$ aqueous solutions in a range of $\mathrm{pH}$ between 0.5 and 1.5. Figure 12 displays the regeneration results, expressed as $\mathrm{Co}^{2+}$ recovered from the saturated adsorbent. The percentage of $\mathrm{Co}^{2+}$ recovered was estimated by mass balance, as shown by the following equations:

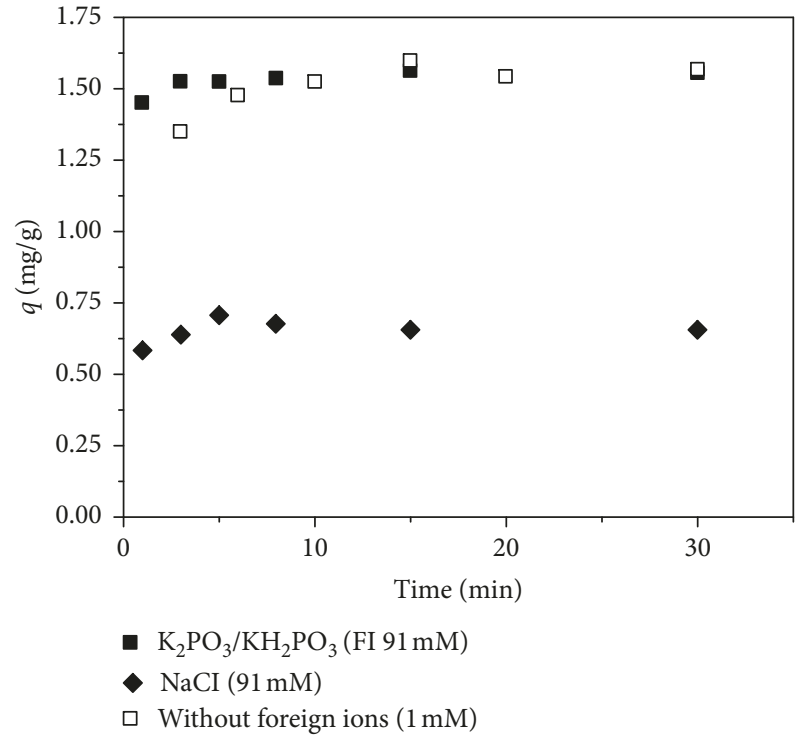

Figure 11: Effect of the controlled $\mathrm{pH}$ on cobalt adsorption using MCSG60A. Conditions: $\left[\mathrm{Co}^{2+}\right]=20 \mathrm{mg} / \mathrm{L}, T=25^{\circ} \mathrm{C}$, adsorbent dosage $=12.5 \mathrm{~g} / \mathrm{L}, \mathrm{pH}$, particle size $=$ powder, and $1100 \mathrm{rpm}$.

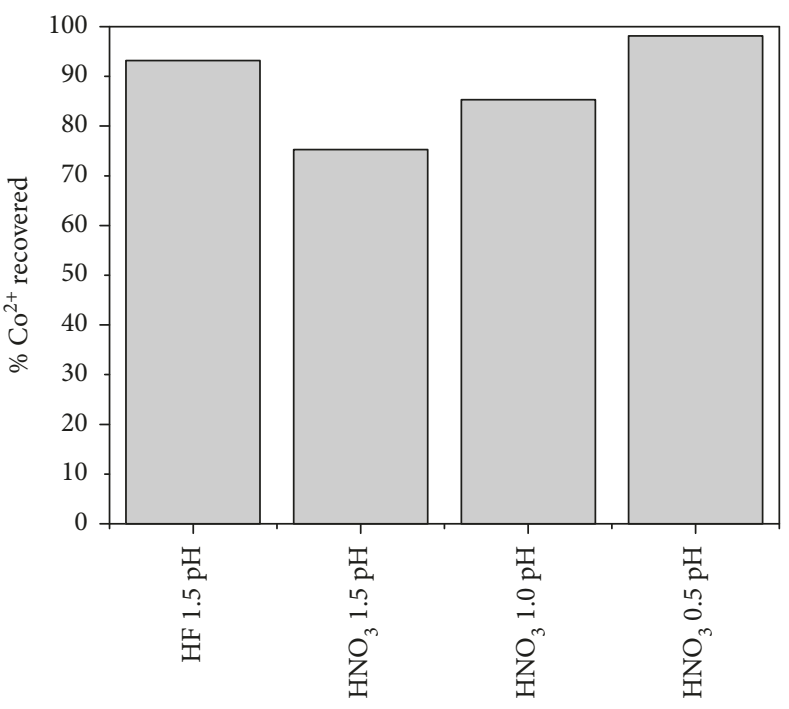

FIgURE 12: MCSG60A regeneration results using different acid solutions. Conditions: adsorbent dosage $=12.5 \mathrm{~g} / \mathrm{L}, T=25^{\circ} \mathrm{C}$, and $1100 \mathrm{rpm}$.

$$
\begin{aligned}
C_{\text {adsorbed }} & =C_{0}-C_{\text {saturation }}, \\
\% \mathrm{Co}_{\text {recovery }}^{2+} & =\frac{C_{\text {adsorbed }}-C_{\text {recovered }}}{C_{\text {adsorbed }}} \cdot 100 .
\end{aligned}
$$

As it can be observed in Figure 12, lower $\mathrm{pH}$ promotes the regeneration of the adsorbent. For instance, when the initial $\mathrm{pH}$ of regenerative solution decreases from 1.5 to 0.5 , the amount of $\mathrm{Co}^{2+}$ recovered from the adsorbent increase around $23 \%$. This is caused by the negatively charged adsorbent surface; this agrees with the potential $Z$ analysis results: if the $\mathrm{pH}$ decreases, the adsorbent surface tends to be positively charged; therefore, the $\mathrm{Co}^{2+}$ ions adsorbed by 
electrostatic interactions onto MCSG60A are rejected. The best regeneration results are achieved with $\mathrm{HNO}_{3}(\mathrm{pH} 0.5)$ solution, which allows recovering the $98 \%$ of the $\mathrm{Ga}^{3+}$ previously adsorbed. A slightly lower percentage of $\mathrm{Co}^{2+}$ was recovered using the recirculated HF solution (93\%). Nevertheless, $\mathrm{HNO}_{3}(\mathrm{pH}$ 0.5) solution was chosen to continue the assays, since it reaches both total cobalt recovery and adsorbent regeneration.

After the regeneration of the adsorbent is achieved, the following step is to concentrate $\mathrm{Co}^{2+}$ so that the water stream is conditioned for its recovery by solvent extraction or electrochemical treatment. To address this, further regeneration experiments were performed decreasing the volume of regenerative dilution $\left(\mathrm{HNO}_{3}, 0.5 \mathrm{pH}\right)$. Figure 13 shows the experiment results.

As displayed in Figure 13, it is possible to concentrate the $\mathrm{Co}^{2+}$ recovered five times, reaching a final concentration of $92 \mathrm{mg} / \mathrm{L}$, if the volume of regenerative solution decreases to the eighth part. Despite cutting the regenerative solution rate, the mass of $\mathrm{Co}^{2+}$ recovered in these cases is between $0.035-0.023 \mathrm{mg}$. For instance, when the volume of regenerative solution is greater than the half part $(1.0 \mathrm{~mL})$, the recovered cobalt mass is $0.035 \mathrm{mg}$, whereas, for the quarter and the eight parts $(0.5$ and $0.25 \mathrm{~mL}$ ), it recovers 0.030 and $0.023 \mathrm{mg}$ of cobalt, respectively. All taken into account, it could be concluded that intraparticle forces promotes the particle agglomeration, preventing cobalt recovery when the amount of adsorbent particles per volume is higher. Thus, it reduces even $35 \%$ the mass of cobalt recovered when the volume of regenerative solution is eight times lower.

\section{Conclusions}

In this research, the influence of kinetic and operating conditions of cobalt adsorption has been studied using a disordered mesoporous activated carbon (MCSG60A). This material showed good properties for the $\mathrm{Co}^{2+}$ removal, adsorbing $90 \%$ of the $\mathrm{Co}^{2+}$ in optimum conditions. These conditions are shown in Table 4:

Moreover, the adsorption of this metal using MCSG60A is fast reaching equilibria in 15 minutes. This adsorbent was employed to assess the effect of adsorption conditions on $\mathrm{Co}^{2+}$ adsorption. Adsorption of the metal ions was found to be highly $\mathrm{pH}$ dependent, being promoted at basic $\mathrm{pH}$. Besides, the adsorbent dosage was found to be directly related to the adsorption capacity, the optimum dosage being $15.0 \mathrm{~g} / \mathrm{L}$. On the other hand, when the particles of activated carbon are larger, the adsorption is impeded and the temperature does not hinder the $\mathrm{Co}^{2+}$ adsorption on MCSG60A. The thermodynamic studies showed that the adsorption is mainly physical since not only $\Delta H^{0}$ proves this but also $\Delta G^{0}$ has the characteristic value of an adsorption process which is mainly due to electrostatic interactions. Furthermore, the presence of foreign cations $\left(\mathrm{Na}^{+}\right.$in the experiments performed) in the solution decreases the cobalt adsorption capacity; this fact is characteristic of physical adsorption since this affects the electrostatic interactions between adsorbent and cobalt.

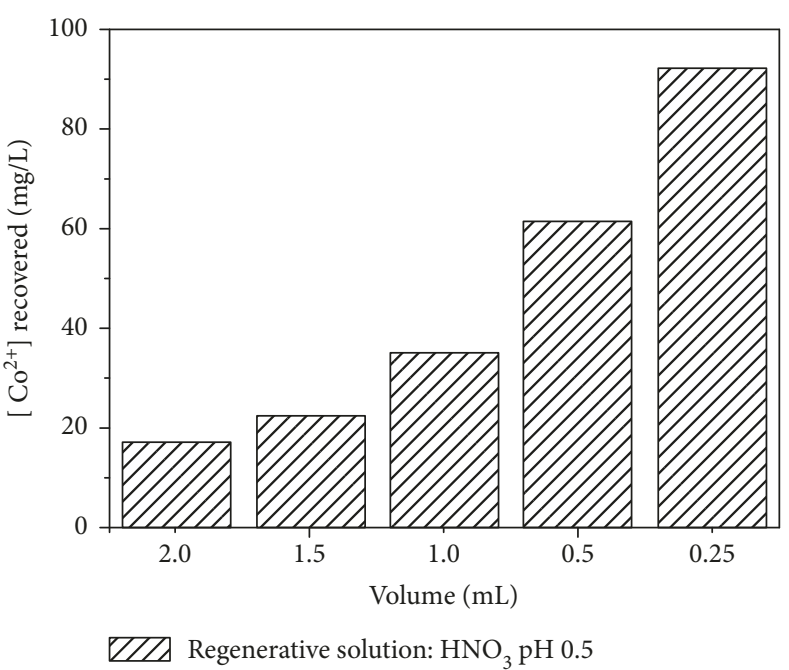

FIgURE 13: Results of the concentration test, decreasing the volume of regenerative solution $\left(\mathrm{HNO}_{3}, 0.5 \mathrm{pH}\right)$.

TABLE 4: Optimum adsorption conditions.

\begin{tabular}{lc}
\hline Parameter & Value \\
\hline Temperature $\left({ }^{\circ} \mathrm{C}\right)$ & 25 \\
Adsorbent dosage $(\mathrm{mg} / \mathrm{g})$ & 12.5 \\
Particle size $(\mathrm{mm})$ & Powder \\
$\mathrm{pH}$ & 6 \\
FI $(\mathrm{mM})$ & 0 \\
Agitation speed $(\mathrm{rpm})$ & 1100 \\
\hline
\end{tabular}

Finally, the $\mathrm{pH}$-controlled test showed that despite the ionic force that involves the buffer solution, the adsorption is not inhibited due to the negatively charged surface that remains steady, keeping the driving force.

Finally, the regeneration results showed that the solution of $\mathrm{HNO}_{3}(0.5 \mathrm{pH})$ allows to recover nearly all the cobalt previously adsorbed (98\%). Also, it is possible to concentrate this metal five times by decreasing the volume of regenerative solution eight times. Thus, adsorption is a suitable option to preconcentrate this metal and facilitate its recovery by solvent extraction or electrochemical treatment.

\section{Data Availability}

The data used to support the findings of this study are included within the article.

\section{Conflicts of Interest}

The authors declare that they have no conflicts of interest.

\section{Acknowledgments}

This work has been financed by the Ministry of Economy and Competitiveness CTQ2014-59011-R (REMEWATER) and CTM2014-53485-REDC (TRAGUANET). 


\section{References}

[1] M. Kobya, E. Demirbas, E. Senturk, and M. Ince, "Adsorption of heavy metal ions from aqueous solutions by activated carbon prepared from apricot stone," Bioresource Technology, vol. 96, no. 13, pp. 1518-1521, 2005.

[2] D. Lison, M. De Boeck, V. Verougstraete, and M. KirschVolders, "Update on the genotoxicity and carcinogenicity of cobalt compounds," Occupational and Environmental Medicine, vol. 58, no. 10, pp. 619-625, 2001.

[3] B. Alloway and D. C. Ayres, Chemical Principles of Environmental Pollution, CRC Press, Boca Raton, FL, USA, 2nd edition, 1993.

[4] US Geological Survey, Mineral Commodity Summaries 2017, US Geological Survey, Reston, VA, USA, 2017.

[5] F. Scheele, E. De Haan, and V. Kiezebrink, Cobalt blues, SOMO Cent. Res. Multinatl. Corp., Amsterdam, Netherlands, 2016.

[6] E. Zanin, J. Scapinello, and M. de Oliveira, "Adsorption of heavy metals from wastewater graphic industry using clinoptilolite zeolite as adsorbent," Process Safety and Environmental Protection, vol. 105, pp. 194-200, 2017.

[7] Z. Liang, W. Shi, Z. Zhao, T. Sun, and F. Cui, "The retained templates as "helpers" for the spherical meso-silica in adsorption of heavy metals and impacts of solution chemistry," Journal of Colloid and Interface Science, vol. 496, pp. 382-390, 2017.

[8] K. Mohammed and O. Sahu, "Bioadsorption and membrane technology for reduction and recovery of chromium from tannery industry wastewater," Environmental Technology \& Innovation, vol. 4, pp. 150-158, 2015.

[9] K. Kadirvelu and C. Namasivayam, "Activated carbon from coconut coirpith as metal adsorbent: adsorption of $\mathrm{Cd}(\mathrm{II})$ from aqueous solution," Advances in Environmental Research, vol. 7, no. 2, pp. 471-478, 2003.

[10] M. Barczak, K. Michalak-Zwierz, K. Gdula, K. TyszczukRotko, R. Dobrowolski, and A. Dąbrowski, "Ordered mesoporous carbons as effective sorbents for removal of heavy metal ions," Microporous and Mesoporous Materials, vol. 211, pp. 162-173, 2015.

[11] Z. Wu, P. A. Webley, and D. Zhao, "Comprehensive study of pore evolution, mesostructural stability, and simultaneous surface functionalization of ordered mesoporous carbon (FDU-15) by wet oxidation as a promising adsorbent," Langmuir, vol. 26, no. 12, pp. 10277-10286, 2010.

[12] W. Peng, H. Li, Y. Liu, and S. Song, "A review on heavy metal ions adsorption from water by graphene oxide and its composites," Journal of Molecular Liquids, vol. 230, pp. 496-504, 2017.

[13] S. Álvarez-Torrellas, G. Ovejero, R. García-Lovera, A. Rodríguez, and J. García, "Synthesis of a mesoporous carbon from peach stones for adsorption of basic dyes from wastewater: kinetics, modeling, and thermodynamic studies," Clean Technologies and Environmental Policy, vol. 18, no. 4, pp. 1085-1096, 2016.

[14] M. M. Hassanien, W. I. Mortada, I. M. Kenawy, and H. El-Daly, "Solid phase extraction and preconcentration of trace gallium, indium, and thallium using new modified amino silica," Applied Spectroscopy, vol. 71, no. 2, pp. 288-299, 2017.

[15] U. U. Jadhav and H. Hocheng, "A review of recovery of metals from industrial waste," Journal of Achievements in Materials and Manufacturing Engineering, vol. 54, no. 2, pp. 159-167, 2012.
[16] S. Chegrouche and A. Bensmaili, "Removal of Ga(III) from aqueous solution by adsorption on activated bentonite using a factorial design," Water Research, vol. 36, no. 11, pp. 28982904, 2002.

[17] U. S. Suryavanshi and S. R. Shukla, "Adsorption of Ga(III) on oxidized coir," Industrial \& Engineering Chemistry Research, vol. 48, no. 2, pp. 870-876, 2009.

[18] J. M. Gómez, E. Díez, I. Bernabé, P. Sáez, and A. Rodríguez, "Effective adsorptive removal of cobalt using mesoporous carbons synthesized by silica gel replica method," Environmental Processes, vol. 5, no. 2, pp. 225-242, 2018.

[19] J. Galán, A. Rodríguez, J. M. Gómez, S. J. Allen, and G. M. Walker, "Reactive dye adsorption onto a novel mesoporous carbon," Chemical Engineering Journal, vol. 219, pp. 62-68, 2013.

[20] C. C. Pavel, D. Vuono, and I. V. Asaftei, "Study of the thermal dehydration of metal-exchange ETS-10 titanosilicate," Molecular Sieves: From Basic Research to Industrial Applications, Proceedings of the 3rd International Zeolite Symposium (3rd FEZA), vol. 158, pp. 805-812, 2005.

[21] F. Yu, Y. Wu, X. Li, and J. Ma, "Kinetic and thermodynamic studies of toluene, ethylbenzene, and $\mathrm{m}$-xylene adsorption from aqueous solutions onto $\mathrm{KOH}$-activated multiwalled carbon nanotubes," Journal of Agricultural and Food Chemistry, vol. 60, no. 50, pp. 12245-12253, 2012.

[22] G. Z. Kyzas, E. A. Deliyanni, and K. A. Matis, "Activated carbons produced by pyrolysis of waste potato peels: cobalt ions removal by adsorption," Colloids and Surfaces A: Physicochemical and Engineering Aspects, vol. 490, pp. 74-83, 2016.

[23] K. A. Krishnan and T. S. Anirudhan, "Kinetic and equilibrium modelling of cobalt(II) adsorption onto bagasse pith based sulphurised activated carbon," Chemical Engineering Journal, vol. 137, no. 2, pp. 257-264, 2008.

[24] P. Tan, J. Sun, and Y. Hu, "Adsorption of $\mathrm{Cu}^{2+}, \mathrm{Cd}^{2+}$ and $\mathrm{Ni}^{2+}$ from aqueous single metal solutions on graphene oxide membranes," Journal of Hazardous Materials, vol. 297, pp. 251-260, 2015.

[25] J. A. S. Moncayo and J. Isaura, Caracterización de la Ácidez de Suelos Volcánicos del Ecuador y su Respuesta al Encalado, Central University of Venezuela, Caracas, Venezuela, 2018. 


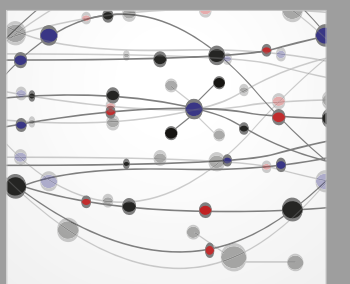

The Scientific World Journal
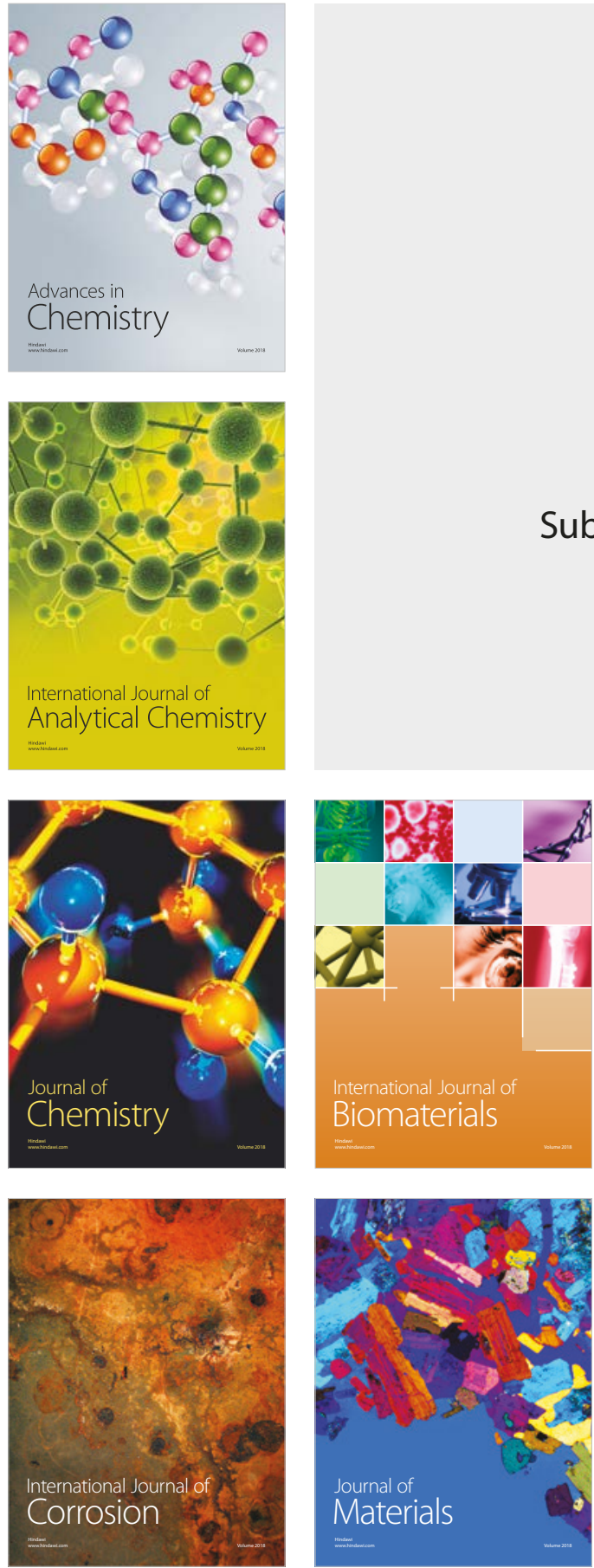

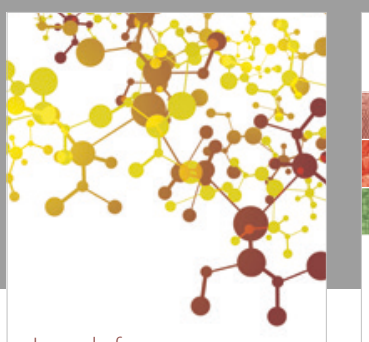

Journal of

Applied Chemistry


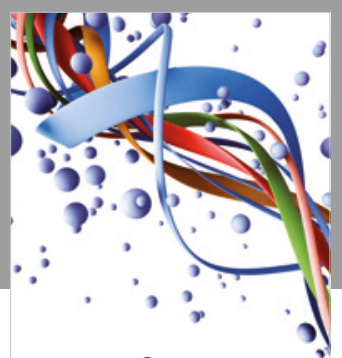

Scientifica

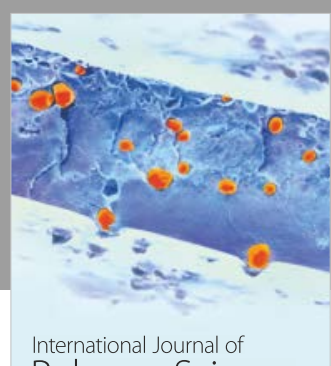

Polymer Science

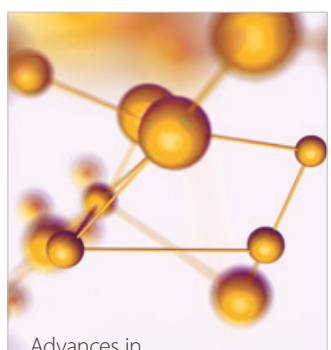

Physical Chemistry
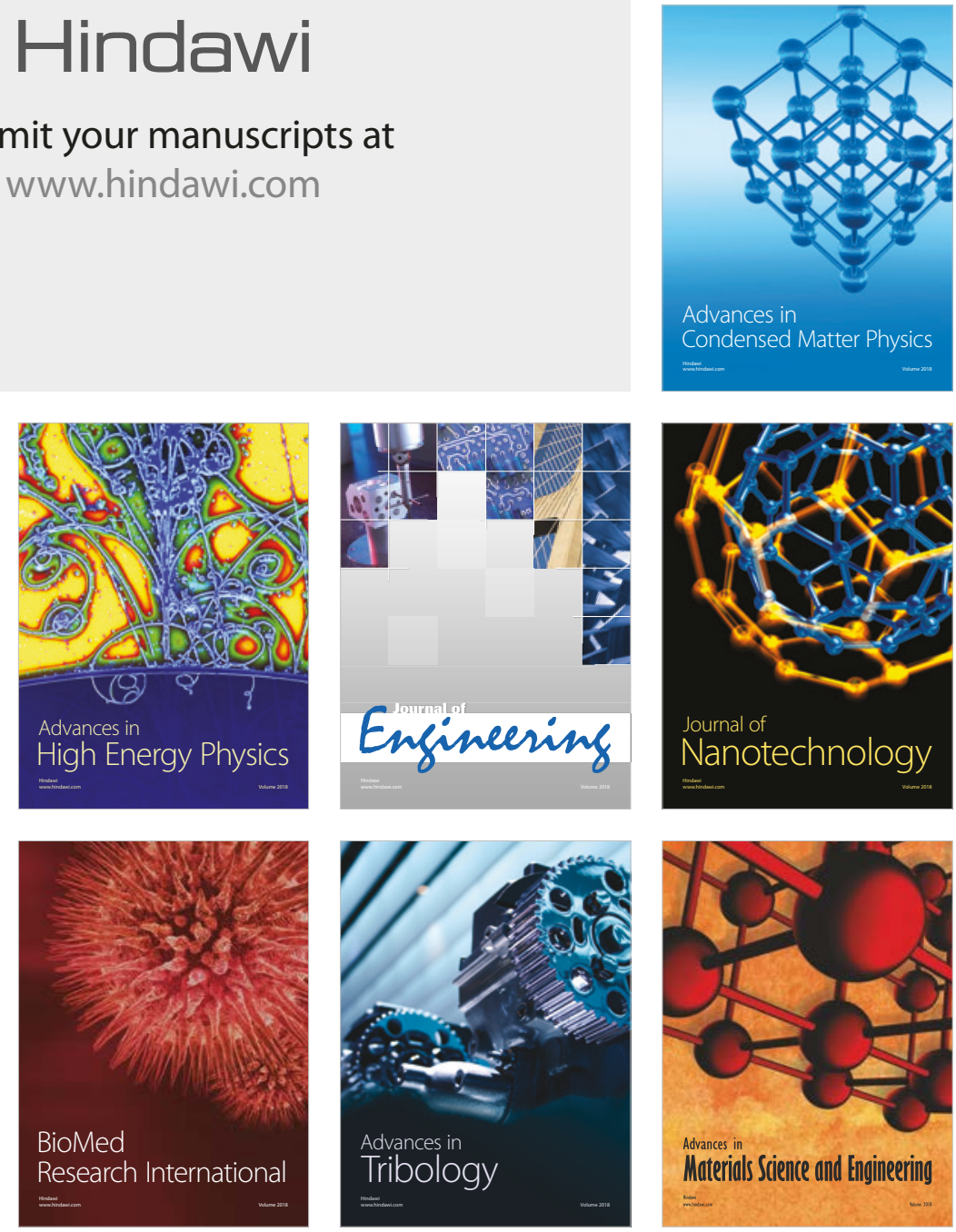